\title{
PERUBAHAN FUNGSI, BENTUK DAN MATERIAL RUMAH ADAT SASAK KARENA MODERNISASI
}

\author{
Ing Julita ${ }^{1}$, Maria Immaculata Hidayatun ${ }^{2}$ \\ 1,2. Jurusan Arsitektur, Fakultas Teknik Sipil dan Perencanaan, Universitas Kristen Petra \\ Jl. Siwalankerto No. 121-131, Surabaya \\ Email: ${ }^{1}$ ingtjiaa@gmail.com, ${ }^{2}$ mariaih@petra.ac.id
}

\begin{abstract}
Abstrak
Seiring dengan berjalannya waktu dan perkembangan teknologi, kebutuhan masyarakat akan berubah atau berevolusi mulai dari aspek sosial maupun budaya. Hal ini akan berpengaruh pada sisi arsitektur dari rumah tinggal masyarakat tak terkecuali rumah adat sekalipun. Rumah adat akan mengalami perubahan arsitektur mulai dari kebutuhan ruang, aktivitas sosial pengguna dan material yang menjadi fokus pada studi ini, yaitu rumah adat Sasak di Lombok, Nusa Tenggara Barat. Perubahan yang banyak terjadi adalah fungsi ruang tempat tinggal dikarenakan berbagai faktor, salah satunya adalah karena penambahan anggota keluarga. Selain itu, penggunaan material juga banyak mengalami perubahan karena faktor ekonomi dan kemajuan teknologi. Oleh karena itu, studi ini akan menganalisis perubahan yang terjadi serta pengaruhnya terhadap makna awal yang terkandung pada rumah adat Sasak karena berbagai faktor pada saat modernisasi.
\end{abstract}

Kata kunci: perubahan fungsi, bentuk, material, rumah adat Sasak, modernisasi.

\begin{abstract}
Title: Function, Form and Material Changes of Sasak Traditional House due to Modernization

Along with the increasing time and technological development, society's needs will change or evolve, starting from the social and cultural aspects. This will affect the architectural side of community dwellings, including traditional houses. Traditional houses will experience architectural changes starting from the needs of space, activities, social users, and materials as in the study to be discussed, the Sasak traditional house in Lombok, West Nusa Tenggara. Many changes that occur are the function of the living space due to various factors, one of which is the addition of family members. The use of material also experienced a lot of changes due to economic factors and technological factors. Therefore, this study will analyze the changes that occur and their influence on the initial meaning contained in the Sasak traditional house due to various factors at the time of modernization.
\end{abstract}

Keywords: function changes, form, material, Sasak traditional house, modernization.

\section{Pendahuluan}

\section{Latar Belakang}

Suku Sasak merupakan penduduk asli di Pulau Lombok, Nusa Tenggara Barat. Sebagai masyarakat asli, suku Sasak memiliki sistem budaya, sebagaimana terekam dalam kitab Nagara Kartha Gama karangan Empu Nala dari Majapahit. Masyarakat Sasak telah mempunyai sistem budaya yang mapan, maka kemampuannya untuk tetap eksis sampai saat ini merupakan salah satu bukti bahwa suku ini mampu menjaga dan melestarikan tradisinya (Anggraeny, 2011). Selain tempat berlindung, rumah tinggal bagi masyarakat Sasak juga memiliki nilai estetika, filosofi dan kehidupan sederhana di masa lampau yang mengandalkan sumber daya alam sebagai mata pencaharian, sekaligus 
sebagai material pembangunan rumah. Dalam masyarakat Sasak, rumah berada dalam dimensi sakral (suci) dan profan duniawi secara bersamaan. Artinya, rumah adat Sasak selain sebagai tempat berlindung dan berkumpulnya anggota keluarga juga menjadi tempat dilaksanakannya ritualritual sakral keagamaan yang merupakan manifestasi dari keyakinan kepada Tuhan, arwah nenek moyang, dan sebagainya.

Rumah tradisional suku Sasak sebagai identitas lokal tidak luput dari fenomena perubahan. Perubahan yang terjadi pada rumah tradisional ini dipengaruhi oleh berbagai faktor, misalnya karena perkembangan zaman dan teknologi, dimana masyarakat mulai bertambah pengetahuannya dan mulai mengenal teknologi yang memudahkan kehidupan. Selain itu, berubahnya mata pencaharian juga menjadi faktor lain penyebab adanya perubahan yang terjadi. Perubahan bentuk rumah tradisional menunjukkan adanya upaya masyarakat untuk bertahan hidup dari perkembangan yang ada serta meningkatkan kehidupan. Adapun pokok bahasan yang dianalisis adalah perubahan apa saja yang terjadi pada bentuk bangunan Bale (rumah tinggal) masyarakat Sasak, terkait dengan fungsi ruang dan fisik bangunan, serta faktor apa yang mempengaruhi perubahan tersebut.

\section{Tinjauan Pustaka}

\section{Modernisasi}

Modernisasi merupakan proses transformasi dari suatu arah perubahan ke arah yang lebih maju/ meningkat dalam berbagai aspek dalam kehidupan masyarakat. Dengan kata lain, modernisasi adalah proses perubahan dari cara tradisional ke cara baru yang lebih maju, dimana dimaksudkan untuk meningkatkan

kesejahteraan masyarakat. Wilbert E. Moore mengemukakan bahwa modernisasi adalah suatu transformasi total kehidupan bersama yang tradisional atau pra modern dalam arti teknologi serta organisasi sosial, ke arah pola ekonomis dan politis yang menjadi ciri-ciri negara Barat yang stabil (Rosana, 2011).

\section{Fungsi, Bentuk dan Material dalam Arsitektur}

Arsitektur merupakan perwujudan fisik wadah atau tempat menampung kegiatan manusia (Surasetja, 2007). Bagaimanapun juga unsur fungsi, bentuk dan ekspresi dari material akan menentukan bagaimana arsitektur dapat bernilai pada suatu karya, memperoleh tanggapan serta mengungkapkan suatu makna. Fungsi merupakan suatu prinsip arsitektur dimana bentuk suatu bangunan harus diperoleh dari fungsi yang harus dipenuhinya; aspek skematis dan teknis dari modernisasi arsitektur (rasionalisme), yang pendirian teoritisnya yang lebih luas juga membentuk pertanyaan simbolik, filsafat, politik, sosial dan ekonomi (Encyclopedia of 20th Century Architecture, 2003). Fungsi, dalam pengertian secara tradisional adalah utilitas, ketepatgunaan, tugas/ guna. Berikut adalah hal yang harus dipenuhi oleh suatu bangunan: feel/ pengaruhnya terhadap pengguna ataupun pengamat; commodity, dari teori Vitruvius tentang commodity, firmness, and delight; firmness/ firmitas dari segi teknik bangunan; dan delight (form). Ketiganya merupakan dimensi yang tidak terpisahkan dari sebuah karya arsitektur dan dengan pengertian bahwa dalam kenyataannya fungsi tidak bisa ada tanpa adanya bentuk dan material konstruksi dan teknik. 


\section{Evolusi Kebudayaan}

Menurut Koentjaraningrat (1996:142), evolusi kebudayaan adalah proses perkembangan kebudayaan umat manusia dari bentuk-bentuk kebudayaan yang sederhana sampai yang makin lama makin kompleks, yang dilanjutkan dengan proses difusi, yaitu penyebaran kebudayaankebudayaan yang terjadi bersamaan dengan perpindahan bangsa-bangsa di muka bumi ini. Koentjaraningrat menyatakan bahwa proses evolusi kebudayaan dapat dianalisis, baik secara mikro maupun secara makro. Proses kebudayaan yang dianalisis secara mikro (detail) dapat memberi gambaran mengenai berbagai proses perubahan yang terjadi dalam kehidupan sehari-hari pada suatu masyarakat.

\section{Perubahan Budaya}

Kebudayaan dengan pranatapranata termasuk kearifan lokal dapat saja berubah bahkan selalu berubah secara dinamis karena tidak ada kebudayaan yang sifatnya statis dan tertutup. Perubahan kebudayaan dapat terjadi karena adanya faktor dari dalam kebudayaan itu sendiri, yaitu bahwa beberapa pranata kebudayaan harus diubah dan disesuaikan dengan perkembangan subyektif yang terdapat dalam kehidupan sosialnya. Perubahan sosial dapat pula terjadi karena adanya kontak dengan pendukung kebudayaan lain. Kisley Davis (Soekanto, 1982:266) berpendapat bahwa perubahan sosial adalah bagian dari perubahan kebudayaan. Perubahan dalam kebudayaan mencakup: kesenian, ilmu pengetahuan, teknologi, filsafat, dan lain sebagainya, bahkan perubahan dalam bentuk serta aturan organisasi sosial. Selanjutnya, Soekanto (1982:283) mengemukakan faktor-faktor yang menyebabkan perubahan sosial dan kebudayaan adalah:

1. Sebab yang bersumber dalam masyarakat itu sendiri:

a). Bertambah atau berkurangnya penduduk.

b). Penemuan-penemuan baru.

c). Pertentangan-pertentangan dalam masyarakat.

d). Terjadinya pemberontakan atau revolusi di dalam tubuh masyarakat itu sendiri.

2. Sebab-sebab yang berasal dari masyarakat:

a). Sebab-sebab yang berasal dari lingkungan fisik yang ada sekitar manusia.

b). Peperangan dengan negara lain.

c). Pengaruh kebudayaan masyarakat lain.

Dari faktor-faktor yang ada, pengaruh yang paling kuat dan penting adalah adanya pengaruh dari masyarakat lain yang dapat diartikan sebagai budaya masyarakat lain yang masuk ke dalam suatu masyarakat itu sendiri. Selain itu, didukungnya oleh waktu yang terus berkembang serta pengetahuan yang semakin luas, menimbulkan adanya perubahan untuk menjadi yang lebih baik.

\section{Metode Penelitian}

Dalam studi ini, digunakan metode penelitian studi kasus-kualitatif. Pengambilan data melalui metode desk based research, yaitu pengambilan data melalui penelitian yang sudah pernah dilakukan. Teknik analisis yang dilakukan adalah dengan mengumpulkan data terlebih dahulu mengenai rumah adat Sasak, Lombok, NTB dan mengecek kualitas dari data yang diambil. Data yang diambil berasal dari penelitian, jurnal dan dokumentasi dari studi literatur. 
Setelah itu dilanjutkan dengan tahap analisis data.

\section{Hasil dan Pembahasan}

Identitas Rumah Tinggal Bale Tani

Bale Tani merupakan rumah tempat tinggal masyarakat Sasak yang memiliki ciri-ciri fisik hanya memiliki satu pintu sempit berukuran rendah dan tidak memiliki jendela. Material yang digunakan untuk Bale Tani adalah jerami untuk bahan atap dan anyaman bambu untuk dinding rumah. Selain itu, lantainya terbuat dari campuran tanah liat, kotoran kerbau dan abu jerami. Penggunaan material lokal tersebut bersumber dari apa yang sudah tersedia di sekitar wilayah tempat tinggal mereka. Hal ini membuat rumah tradisional Sasak memiliki nilai lokal yang unik dan memiliki makna tersendiri (Laksmana, 2012).

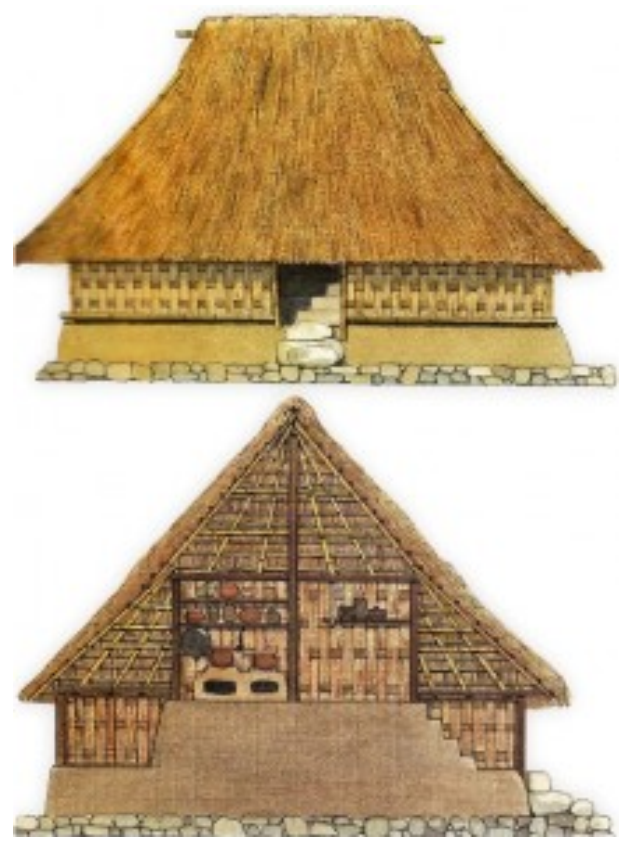

Gambar 1. Tampak dan potongan Bale Tani Sumber:

https://fitanisya.files.wordpress.com/2015/03/r umah-sasak-217x300.jpg

Bale Tani sendiri pada awalnya terdiri dari satu bale dalem dan satu serambi.
Bale dalem diisi dengan ruang tidur khusus untuk wanita dan pawon/ dapur pada ruang sebelahnya. Sedangkan bagian serambi (sesangkok) digunakan sebagai ruang tamu dan ruang tidur untuk pria. Bale dalem dan bagian serambi dihubungkan dengan tangga.

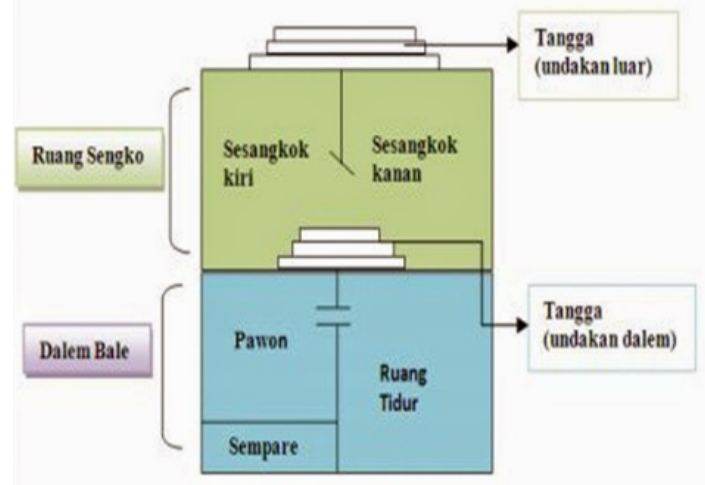

Gambar 2. Layout ruang Bale Tani Sumber: Laksmana, 2012

\section{Elemen Bangunan}

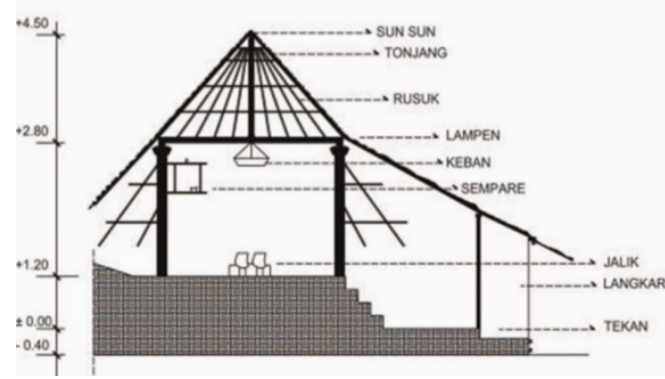

Gambar 3. Potongan Bale Tani Sumber: Laksmana, 2012

Bentuk atap yang meninggi di bagian belakang melambangkan hubungan manusia dengan Tuhan. Sedangkan sosoran atap di bagian depan melambangkan hubungan manusia dengan sesama. Material struktur atap menggunakan bambu dengan sambungan menggunakan pasak (paku bambu) dan ikat menggunakan tali bambu. 


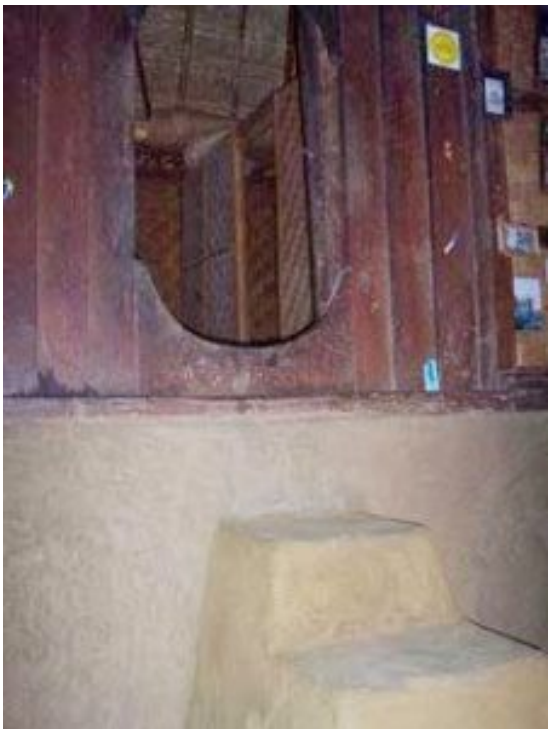

Gambar 4. Elemen pintu yang menghubungkan bale dalem dan serambi Sumber: https:/gpswisataindonesia.info/wpcontent/uploads/2014/03/86f7f-sasak-02$225 \times 300 . j p g$

Dinding rumah menggunakan anyaman bambu jenis Sasak dan penggunaannya dimaksudkan agar udara tetap masuk ke dalam ruang melalui lubang-lubang kecil yang tercipta sebagai pori-pori dari dinding anyaman. Elemen pintu hanya terdapat pada pintu masuk dan di dalam ruangan untuk menghubungkan bale dalem dan serambi. Pintu yang digunakan cenderung berukuran rendah dengan tujuan saat masuk ke dalam rumah sambil menunduk, menandakan sikap rendah hati dan memberi salam kepada pemilik rumah. Material pintu utama menggunakan anyaman bambu dan untuk pintu di dalam menggunakan sistem geser dan terbuat dari kayu.

\section{Perubahan Fungsi pada Layout Bale Tani}

Perubahan fungsi yang terjadi akibat faktor masyarakat sendiri, yaitu perubahan fungsi pawon/ dapur pada bagian bale dalam menjadi tempat penyimpanan (ruang gabah). Hal ini terjadi karena tuntutan pekerjaan (bisnis) masyarakat sehingga menambah kebutuhan ruang pada bangunan tempat tinggal. Pada dasarnya, tempat penyimpanan bahan makanan seperti gabah akan disimpan pada bangunan lumbung yang terletak di sebelah Bale Tani. Akan tetapi, penggunaan lumbung digunakan untuk menyimpan bahan makanan yang akan digunakan sendiri untuk kebutuhan makan masyarakat Sasak sendiri. Sedangkan bahan makanan untuk kebutuhan pekerjaan atau bisnis individu dibutuhkan ruang baru dalam rumah sehingga fungsi asli dari ruangan tersebut berubah karena tuntutan ini. Dengan demikian, perubahan ini akan berpengaruh terhadap lokasi letak pawon/ dapur yang tergantikan. Pada satu kasus, penambahan massa bangunan di sebelah serambi akan dilakukan untuk dijadikan sebagai pawon/ dapur. Hal ini akan berpengaruh terhadap bentuk bangunan sehingga berbeda dengan aslinya, yaitu dengan menambahkan elemen atap dan fasad bangunan yang semakin memanjang.
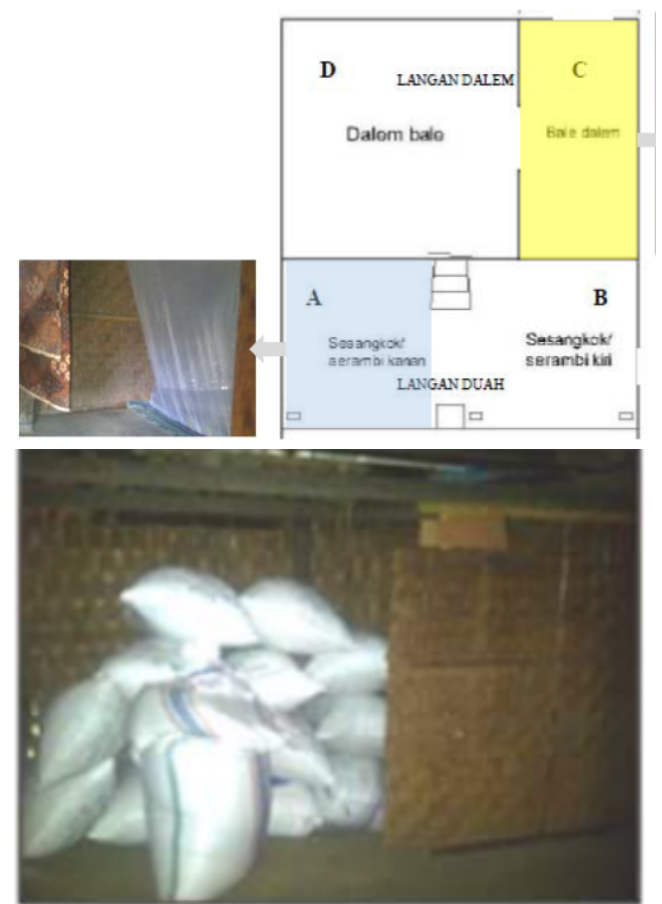

Gambar 5. Perubahan layout Bale Tani menjadi ruang bayi dan tempat gabah Sumber: Dokumentasi penulis, 2019 


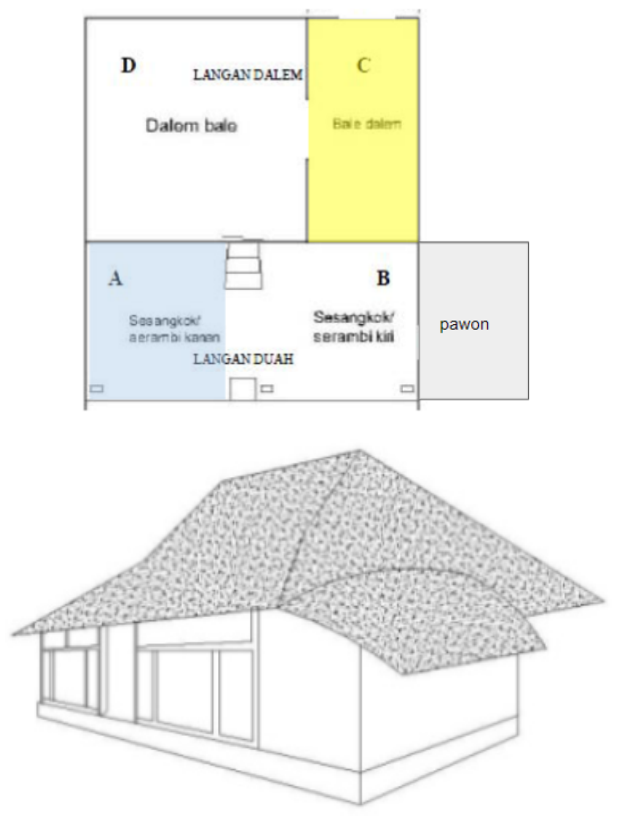

Gambar 6. Penambahan massa bangunan untuk fungsi pawon/ dapur

Sumber: Dokumentasi penulis, 2019

Perubahan selanjutnya terjadi pada bagian serambi yang pada awalnya digunakan sebagai ruang tidur untuk pria dan ruang tamu. Karena adanya faktor penambahan anggota keluarga baru, maka berpindah fungsinya menjadi kamar bayi.

\section{Perubahan Elemen Dinding dan Pintu}

Elemen dinding yang menggunakan anyaman bambu dengan motif atau jenis anyam Sasak diubah dan dimodifikasi dengan jenis atau anyaman atau motif yang lain yang lebih beragam. Hal ini dapat terjadi karena dinding yang lama telah rusak dan pemilik rumah menginginkan sesuatu yang baru, yaitu dinding rumah lebih awet dengan tetap menggunakan material bambu yang lebih bagus. Perubahan ini dapat terjadi karena seiring berkembangnya zaman dan teknologi yang sudah maju serta bertambahnya pengetahuan masyarakat sehingga terdorong untuk melakukan eksplorasi dari material yang sudah ada.

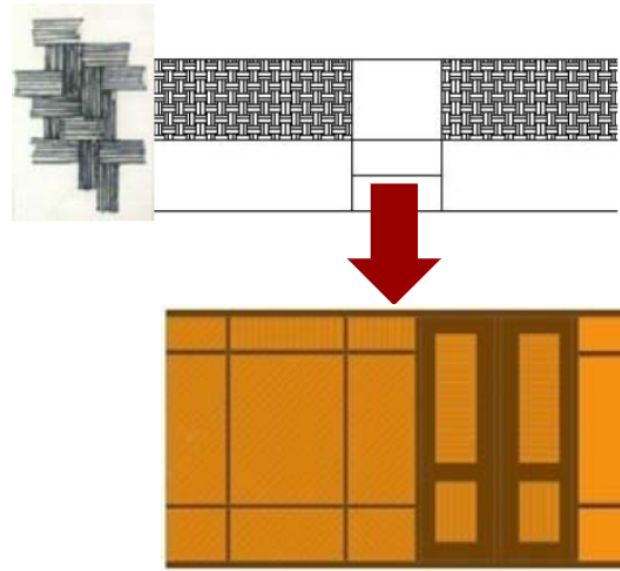

Gambar 7. Perubahan jenis/ motif anyaman bambu pada dinding

Sumber: Dokumentasi Anggraeny, 2011

Selain karena ingin tahan lama dan kuat (faktor kebutuhan), elemen pintu juga diubah karena faktor estetika bangunan. Pintu yang menggunakan sistem geser perlahan mengalami beberapa perubahan. Pada perubahan pertama, material masih menggunakan bambu tetapi sistem geser diubah menjadi sistem dorong yang sudah menggunakan dua pintu. Selanjutnya, diubah lagi menjadi pintu dorong dua pintu dengan mengganti material bambu menjadi kayu.

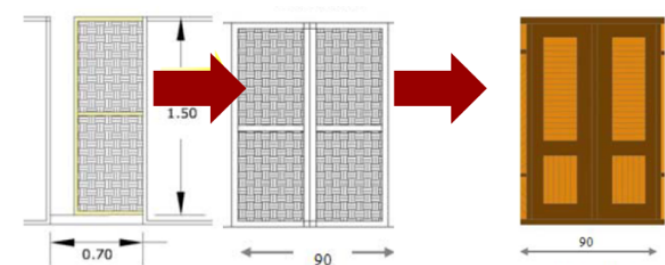

Gambar 8. Perubahan material dan sistem pada elemen pintu

Sumber: Dokumentasi Anggraeny, 2011

Pintu yang menghubungkan bale dalem dan serambi dihilangkan lengkungnya, tetapi sistem masih tetap menggunakan pintu geser dan material kayu. Perubahan ini terjadi dikarenakan faktor perawatan dan ekonomi. 


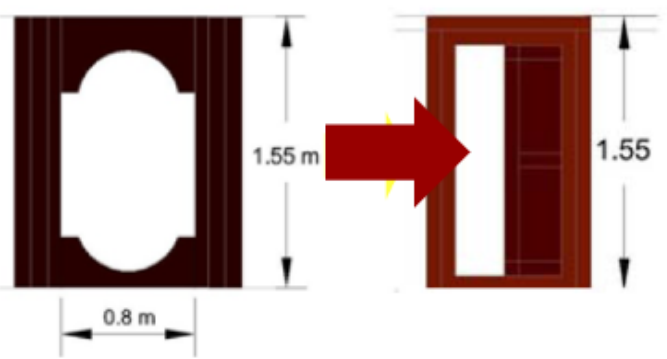

Gambar 9. Perubahan bentuk pintu yang menghubungkan bale dalem dan serambi Sumber: Dokumentasi Anggraeny, 2011

\section{Perubahan Elemen Atap}

Perubahan pada elemen atap terjadi pada penggantian material tali bambu, yang pada awalnya digunakan sebagai pengikat struktur bambu pada atap, menjadi material tali nilon. Hal ini terjadi karena adanya perubahan kebudayaan (Koentjaraningrat, 1996) dalam hal pengetahuan, yaitu pengetahuan warga akan material yang lebih modern dan baru.
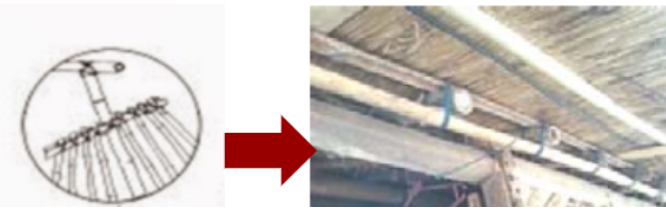

Gambar 10. Material pengikat tali bambu menjadi tali nilon pada atap Sumber: Dokumentasi Penulis

\section{Perubahan Fasad Bangunan}

Berdasarkan ciri-ciri dari rumah adat Sasak, Bale Tani tidak memiliki jendela dan hanya terdapat satu pintu masuk, yaitu sebagai pintu masuk utama. Karena faktor perubahan iklim (faktor geografis) yang tidak menentu dikarenakan fenomena global warming, maka kebutuhan akan kenyamanan masyarakat dalam rumah juga akan berubah. Hal ini membuktikan bahwa dengan adanya perubahan iklim, kemudian disikapi manusia dengan pengetahuan untuk menyelesaikan masalah. Penambahan jendela sebagai ventilasi dan tempat pertukaran udara dilakukan pada sebagian besar fasad bangunan terutama pada bagian depan.

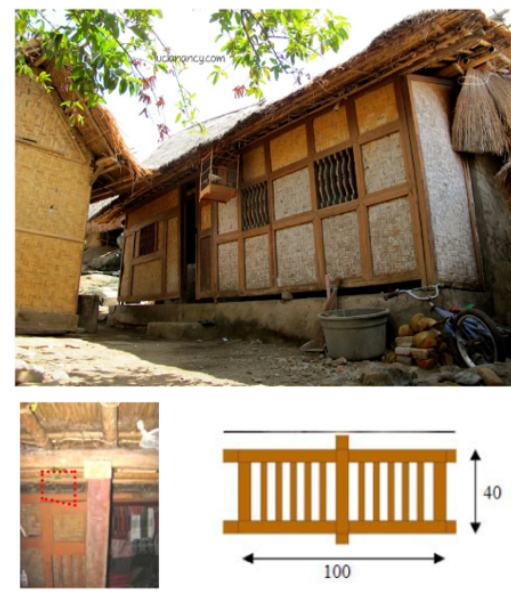

Gambar 11. Penambahan kisi pada dinding Sumber: Dokumentasi penulis, 2019

\section{Kesimpulan}

Semua perubahan yang terjadi pada rumah tinggal masyarakat Sasak, yaitu Bale Tani, meliputi perubahan fungsi layout, perubahan penggunaan material berpengaruh terhadap perubahan bentuk pada elemen-elemen bangunan lainnya. Perubahan ini paling banyak disebabkan oleh faktor waktu dan berkembangnya kebutuhan manusia dari aspek sosial, ekonomi dan budaya. Hal ini membuktikan bahwa modernisasi berdampak pada berkembangnya teknologi, dengan demikian maka berkembang pula pengetahuan manusia akan material, bentuk dan kefungsian dalam ruang. Sehingga, manusia terdorong untuk melakukan eksplorasi dan modifikasi pada sesuatu yang sudah disediakan oleh alam. Selain itu, dengan kemajuan pengetahuan manusia cenderung untuk berpikir lebih maju untuk menanggapi isu atau fenomena yang terjadi pada saat ini. Salah satunya adalah masalah tentang perubahan iklim di wilayah mereka yang tidak menentu, dikarenakan adanya global warming. Perubahan-perubahan terjadi karena adanya tuntutan-tuntutan kebutuhan 
terhadap kenyamanan penghuni, meskipun demikian, dalam perubahan yang dilakukan masih terlihat upaya masyarakat untuk tetap mempertahankan prinsip rumah adat mereka.

\section{Daftar Pustaka}

Anggraeny, N.F., Antariksa, Suryasari, N. (2011). Perubahan bentuk bangunan Bale Tani dan Bale Bontar di Dusun Sade Lombok Tengah. Arsitektur e-Journal, Volume 4, Nomor 2, Juli 2011, 123-142.

Koentjaraningrat. (1996). Pengantar Antropologi 1. Jakarta: Rineka Cipta.

Laksmana, F.M. (2012). Arsitektur tradisional Nusa Tenggara Barat (NTB) suku Sasak. Diunduh dari http://www.mozaikarsitek.com/2 014/12/arsitekrur-tradisionalsuku-sasak-ntb.html

Rosana, E. (2011). Modernisasi dan perubahan sosial. Jurnal Tapis: Jurnal Teropong Aspirasi Politik Islam, Volume 7, Nomor 1, 4662.

Sennott, R.S. (Ed.). (2003). Encyclopedia of $20^{\text {th }}$ century architecture. London: Routledge.

Soekanto, S. (1982). Sosiologi: Suatu pengantar. Jakarta: Rajawali.

Surasetja, R. I. (2007). Fungsi, ruang, bentuk dan ekspresi dalam arsitektur. (Bahan Ajar TA 110 Pengantar Arsitektur, Program Studi Arsitektur Jurusan Pendidikan Teknik Bangunan FPTK UPI, 2007). Diunduh dari http://file.upi.edu/Direktori/FPT K/JUR.PEND. TEKNIK_ARSI TEKTUR/196002051987031R. IRAWAN_SURASETJA/Ha nd Out/FUNGSI RUANG BEN TUK_DAN_EKSPRESI.pdf 